\title{
Endogenous Parathyroid Hormone-Related Peptide Action on Bone Matrix Formation
}

Katsuaki Motomura, Yoshiro Tsuji and Shunichi Yamashita

Department of Pediatrics (KM, YT), Department of Cell Physiology-Atomic Disease Institute (KM, SY), Nagasaki University School of Medicine, Nagasaki, Japan

Key words: parathyroid hormone-related peptide, bone matrix formation, osteoblast

Parathyroid-hormone-related peptide(PT $\mathrm{HrP}$ ) was initially discovered to be the main factor of the syndrome of humoral hypercalcemia of malignancy (HHM)(1); subsequently, the PTHrP gene has been shown to be expressed in a wide variety of normal tissues. As its receptor, common for PTH and PTHrP(2), also shows broad expression, attention has been focused on its physiological role in autocrine/paracrine fashion (3).

Concerning the role of PTHrP in bone metabolism, there is no direct evidence that it induces bone matrix formation, especially from in vitro studies. For a long time, however, many investigators have supposed the existence of diseases caused by PTH/PTHrP receptor dysfunction in mammals and indeed several groups have aimed at and thoroughly investigated abnormalities of the PTH/PTHrP receptor gene in patients with congenital bone disorders. Finally, the nobel mutant PTH/ $\mathrm{PTHrP}$ receptor, which is constitutively active in cases of Jansen-type metaphyseal chon-

Correspondence: Dr. Katsuaki Motomura, Reserch Scholar- Medecal Research, Endocrinology Section WlllD, West Los Angeles VA Medical Center, 11301 Whilshire Blvd., Los Angeles, CA 90073, USA.
drodysplasia(JMC), was firstly reported by H.Juppner et al.(4). They have also clarified ligand-independent constitutive cAMP accumulation using an in vitro transfection assay, which provided a way of understanding the unique phenotype of JMC, severe ligand-independent hypercalcemia and hypophosphataemia.

Furthermore, there are several reports of in vivo gene manipulations using PTHrP and PTH/PTHrP receptor genes. In 1994, Karaplis et al. reported PTHrP-depleted mice $(5,6)$ which were moribund and died soon after birth, and showed short extremities and pathological 1)acceleration of endochondral mineralization, and 2)replacement of normal cartilage in a prematurely mineralized area. In contrast, mice whose $\mathrm{PHP} / \mathrm{PTH} \mathrm{P}$ receptor had been knocked out showed a similar phenotype, but they died before birth. Subsequently the same group presented the attractive hypothesis that endogenous PTHrP is localized in the nucleus and serves not only as ligand for classical receptor signal transduction, but also to enhance the apoptotic cell death pathway of the chondrocyte(7). This hypothesis reminds us of the importance of 


\section{Motomura et al.}

using an endogenously produced peptide when we analyze the effect of peptide on target cells. In conjunction with the possible role of endogenous PTHrP on chondrocytes, overexpression of PTHrP in chondrocytes causes a marked delay in the developmental program of chondrocyte differentiation and endochondral ossification(8). Interestingly these transgenic mice showed a similar phenotype to that of the human JMC mentioned above. These studies have clarified the effect of PTHrP on the chondrocyte through an autocrine/paracrine mechanism. Another target organ, bone, should therefore be analyzed as the next step, because the previous studies did not give any precise information on the PTHrP effect on the osteoblast.

Several reports have touched on this effect on the osteoblast, although, in many cases, results are still controversial and limited to the effect of exogenous PTHrP fragments, not of endogenous intact PTHrP peptide. For further investigation, we made a stable transfected osteoblast which could express a whole intact PTHrP (1-141), and analyzed its phenotype in vivo using implantation of cells into the subcutaneous tissues of allologous rats. Our results demonstrated that the tumor tissues, derived from a stable PTHrP (1-141) overexpressing the ROS cell line, showed significant acceleration of bone matrix formation and subsequent mineralization compared to the original ROS cells. Furthermore, the osteoblast phenotypic gene, and in particular osteocalcin mRNA expression, was upregulated in tissue derived from transfected cells in vivo. Downregulated PTH/PTHrP receptor levels were restored in these tumor tissues. In contrast, all implanted rats showed normal levels of cal-
Table 1 Endogenous PTHrP effect on mineralization and matrix formation in osteoblasts

\begin{tabular}{lcc} 
& in vitro & in vivo \\
\hline matrix formation & - or & 1 \\
mineralization & 1 & \\
\hline
\end{tabular}

cium, phosphorus and PTHrP in the serum, and they did not show any generalized abnormalities indicating a localized effect of PTHrP within the tumor tissues. The results are summarized in Table 1. The precise mechanisms of the action of endogenous PTHrP on osteoblastic osteogenesis should be clarified; however, in recent reports, nobel PTH-specific receptor (PTH2-receptor) has been cloned(9), which might encourage us to seek another type of PTHrP specific receptor. The action of PTHrP on bone matrix formation is regulated in a complicated manner, but PTHrP is now considered to be an important accelerator of in vivo bone matrix formation.

\section{References}

1. Martin TJ, Suva LJ, Parathyroid hormone-related protein: a novel gene product. (Review). Bailliere. Clin Endoc 1988; 2: 1003-29.

2. Abou-Samra AB, Juppner H, Force T, Freeman MW, Kong XF, Schipani E, et al. Expression cloning of a common receptor for parathyroid hormone and parathyroid hormone-related peptide from rat osteoblast-like cells: a single receptor stimulates intracellular accumulation of both cAMP and inositol trisphosphates and increases intracellular free calcium. Proc Natl Acad Sci USA 1992; 89: 2732-6. 


\section{PTHrP Action on Bone Matrix Formation}

3. Enomoto H, Yamashita S, Usa T, Namba $\mathrm{H}$, Ohtsuru A, Villadolid $\mathrm{MC}$, et al. Autocrine/paracrine function of parathyroid hormone-related peptide in rat osteoblast-like cells. Biochem. Biophys. Res Commun 1993; 191: 1261-9.

4. Schipani E, Kruse K, Juppner HA. Constitutively active mutant PTH-PTHrP receptor in Jansen-type metaphyseal chondrodysplasia. Science 1995; 268: 98100.

5. Karaplis AC, Luz A, Glowacki J, Bronson RT, Tybulewicz VL, Kronenberg HM, et al. Lethal skeletal dysplasia from targeted disruption of the parathyroid hormonerelated peptide gene. Genes Dev 1994; 8: 277-89.

6. Amizuka N, Warshawsky H, Henderson JE, Goltzman D, Karaplis AC. Parathyroid hormone-related peptide-depleted mice show abnormal epiphyseal cartilage development and altered endochondral bone formation. J Cell Biol 1994; 126: 1611-23.

7. Henderson JE, Amizuka N, Warshawsky $\mathrm{H}$, Biasotto D, Lanske BMK, Goltzman D, et al. Nucleolar Localization of Parathyroid Hormone-Related Peptide Enhances Survival of Chondrocytes under Conditions That Promote Apoptotic Cell Death. Mol Cell Biol 1995; 15: 4064-75.

8. Weir E, Philbrick W, Neff L, Amling M, Baron R, Broadus A. Targeted overexpression of parathyroid hormone-related peptide in chondrocytes causes skeletal dysplasia and delayed osteogenesis. J Bone Miner Res 1995; 10: (S157) 74.

9. Usdin TB, Gruber C, Bonner TI. Identification and functional expression of a receptor selectively recognizing parathyroid hormone, the PTH2 receptor. J Biol Chem 1995; 270: 15455-8. 